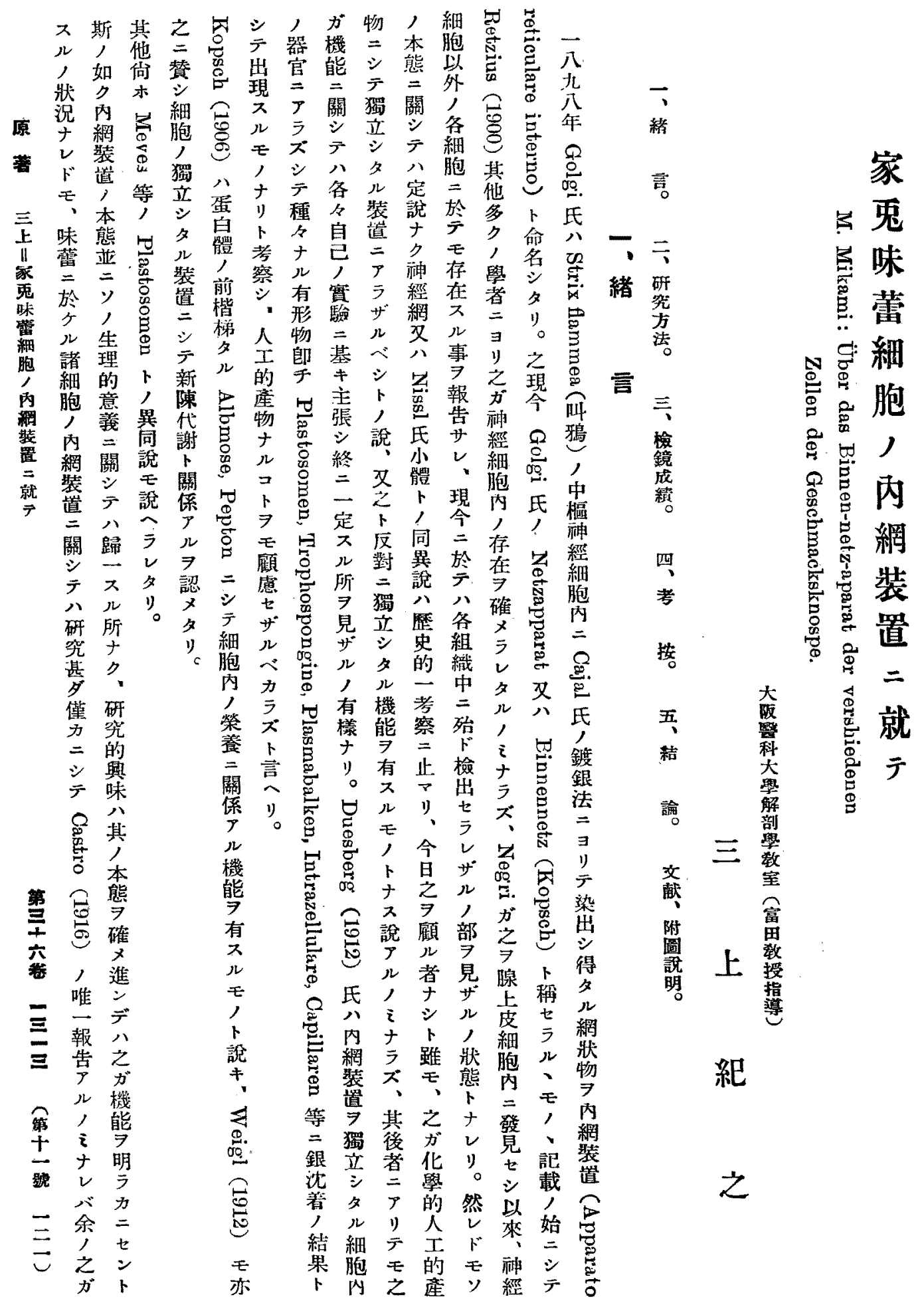




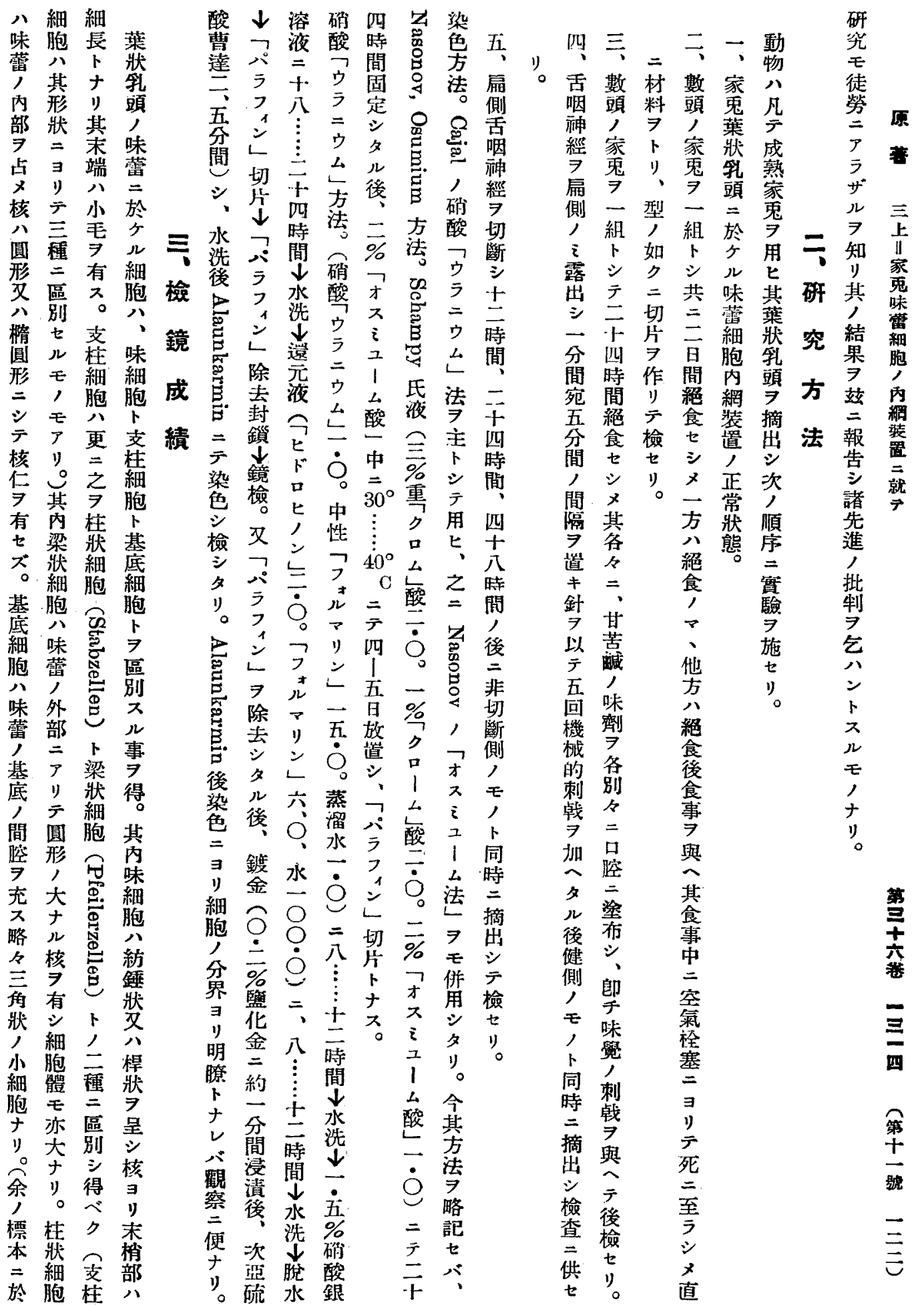




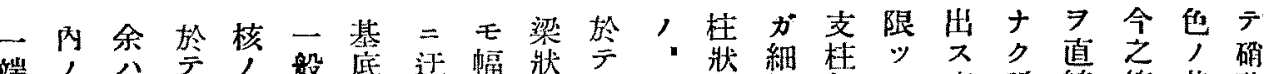

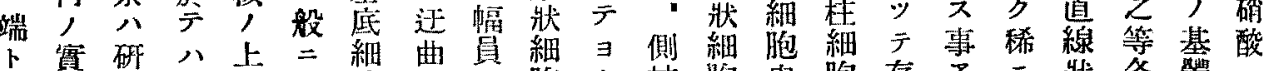
モ 䮦笔更部之胞シ心胞り枝胞內胞存〉狀各體

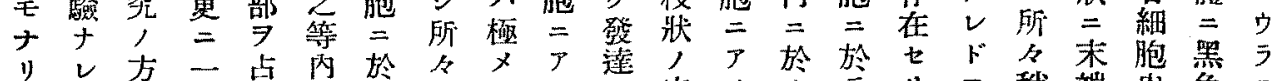

原りし方一占內於\&

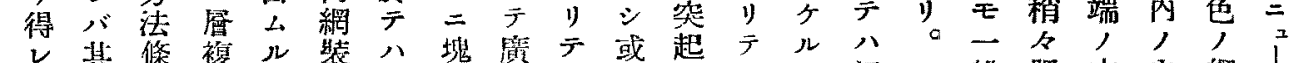

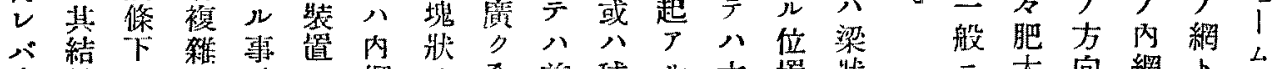

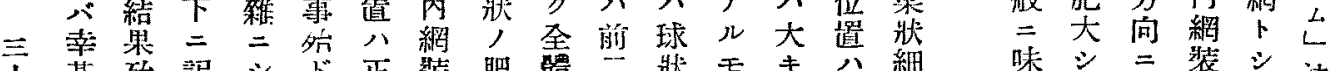

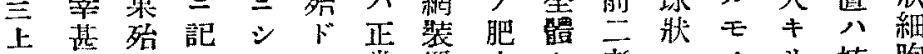
II

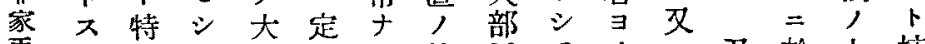

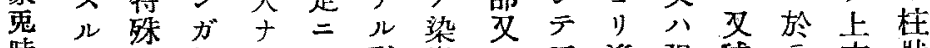

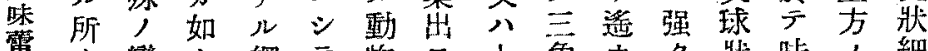
雷ナ變キ網テ物ス小角カ品味, 細 胞り花方狀味 $=ル$ 環狀二迂, 細原胞 內。要法 $尹$ 細於モ牀, 强曲肥胞形上

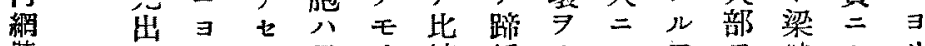

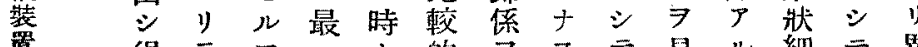

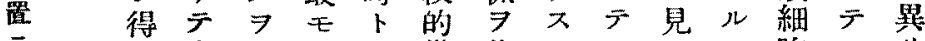

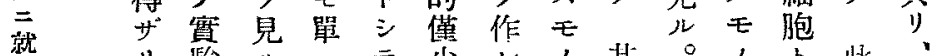

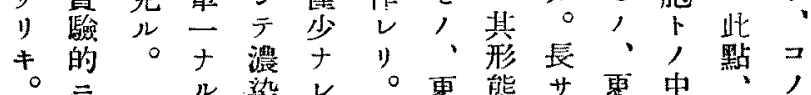

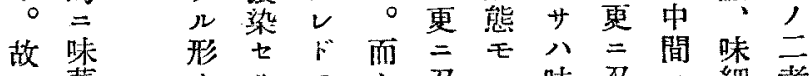

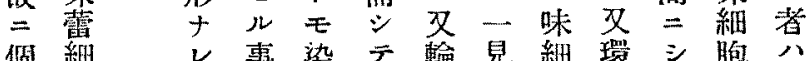

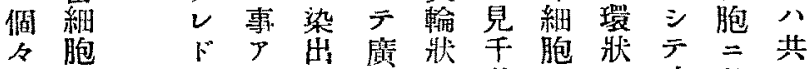
, 内丙七斗差考, 味於二 成, 柱、儿基ナ满りモ細ケ味 續内狀及モ底 又别短, 胞儿細 二網細薄, $尹$ モ大力多三モ胞

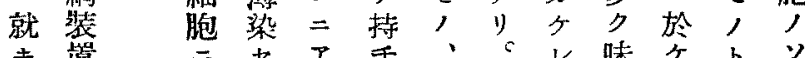

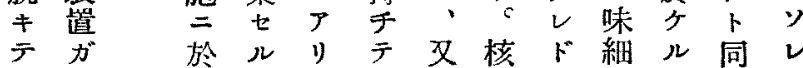

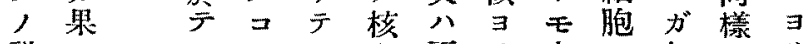
詳 シ $、$ 八三不》太气如なり

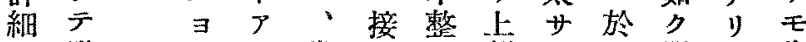

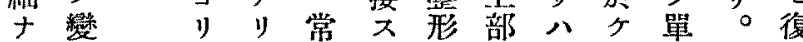
ル化 太 $テ$ テ ル, 却ル-

記 ス

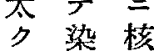
跤 ル 澼 否 广

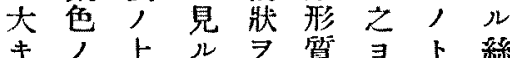
$\Rightarrow$ 網 原 $\doteqdot$ モ キ业古 z 7 形 態 シ 小 三 $\quad$ 齐

五 括 夕 的 稍 復 物 複向常 ニド 襍—䍄

能 述 モ

+ 尔

程十牀

來儿上

㫿 目

三能

單的

三 $\quad$ 參

溜ザ

森

緗 太元

㐱星

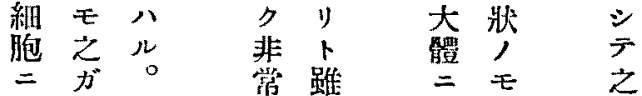

又、虫量,

モ存十的气

, 在り

万纰

リル ル 較

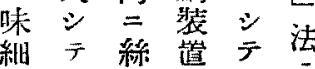
胞聯狀光發 ，珠 二 正現 》 千, 狀 走 常 ᄌ。 八ナ、寻少

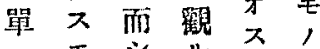
一 三 7 其各 $\left.\right|^{2}$ 黄 テり。起細山色 細。始胞文端 基 直科公 線接橴り 爻 $=$ テ リ黑 僅二沝其 形色 力本二態モ絧 二, 肥 $\exists$, ; 通絣厚異 心シ 曲狀スル帶 现 沙星モり。淡更 狀出喿色鍍 呈琶、脃基金

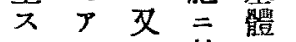
モり七於 或儿从色 $\Rightarrow$ 壬核

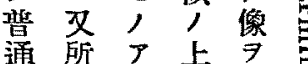
今\&方見 $*=ト ゙=ル=$ 且橝 モ

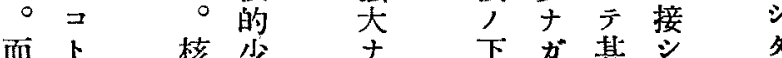

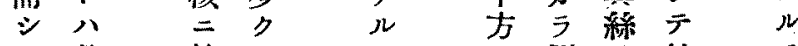

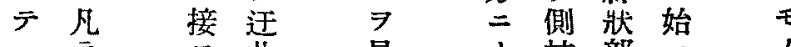
․ 万明見 般同 ル七

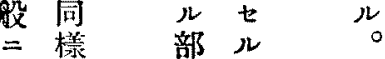

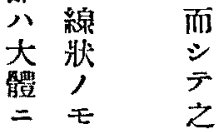
ク哭 必小主細利 上. 突 = 胞 テ 方起戀䚀 
轉 原 ズ同 然明裂力味

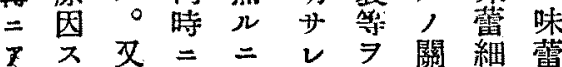
ラ儿生、余 $\%$ 来伱胞細 ザモ㻎生, 、ス 儿, 的理味 $>$ 千示於, $+ナ$, 的菅り, ス每

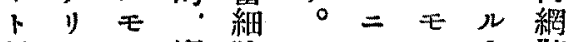

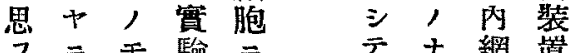

$=千$ =

千就常 的望

）二， 尔

$ナ テ$ 同モル

リ八-人研

。各十其 染

郎方儿自二

于面王身際

材人,

料 研 = 間

切究 $r=$ 余

取二 或,

時 侯 ズ程 行 ) $\%$ 度

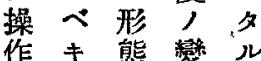

千 =化 船

图, 广園

定二數ル列

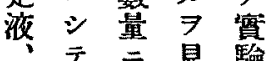

跟 容大夕的

淮易小り,

還 $=$ 。元

㫕馀差㻣，

：的同、

僅 得 $\exists$ 堹

カ ザ 認貿 理

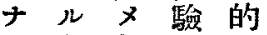

儿所得 $\Rightarrow$ 正

䖯ナルナ常

及ドタル

ビモナルモ

其、り千,

等余展,

用最然占，

モ 犬䖵

ル大乙偣何

時与等 常 等

間 $;$ 同;

的愿内 一羕

關因網 成 異

係, 装續 7

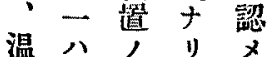

度り

光化 言 ザ

光染心 染们 7 色

線色侐
ル 裝 二

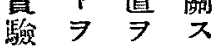

的矮形儿

, 八態 研

₹之的癹

$\because$ 和

病夕繁儿

的り 少二六

千一向年

，船末

或內 方蚟

八 網 惯

生装䮦，

理㯰的, 菜

, 戀操

千化作

, ᄌᄌ ,

= $ル i$

於二事二

夕 常二

ル

之 $\div$ リ他

等、如 =

赫, ソ 们 交

化位儿 7

八置見

細, 化

移來サ

活、

動整ヤ会

八的㕛

機增 $ソ$ 本

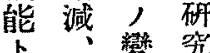

關形化二

係 態 齐 $\exists$

$\Rightarrow$ 的絊少

有 慗胞家

ス化公菟

モ前能 狀

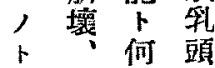

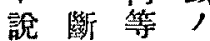

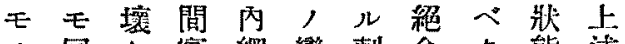

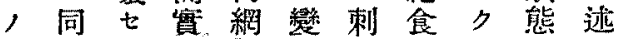

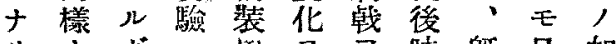

リナガ二正 $ア \Rightarrow$ 昧兓日如

○ $ル$ 如 於 $=$ 甚 學 = 數 ク

勿狀引

猃 7 斷 八等認夕战學多

神ナ裂 正特 特儿方者ク貝

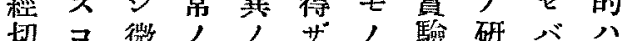

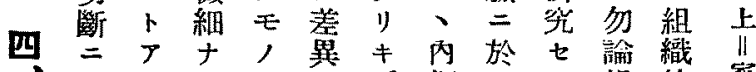

-

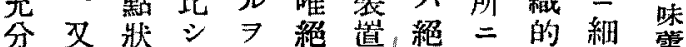

斯 顆テ認食 $尹$ 食シ, 胞細

注 盖何 $メ$ 動 互二デ戀二胞

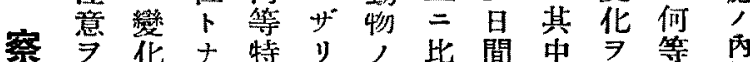

拂, 曰別 $\neq$ 味較後三來變 網

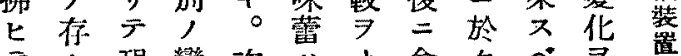

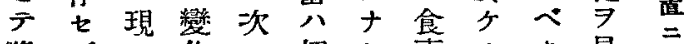

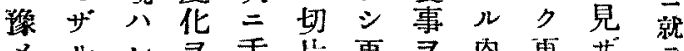

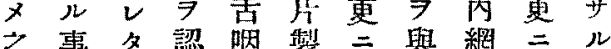

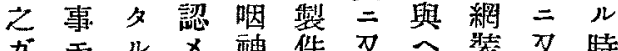

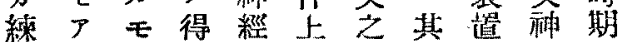

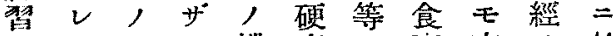

ヨバアリ機度, 事亦, 於

+ 余 $y \neq$ 械 7 中謷刺

分卜。的增, ，化钱果

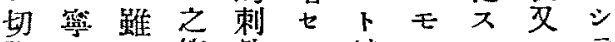

所断等战儿健, ルハテ

=乙㫮, 二 夕康、它之內

詔 7 同成 $\exists メ$ 正昧, ガ絸

$ナ$ 染一績儿谌常蕾夕切哇

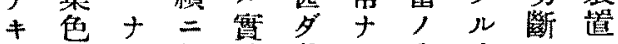

$\Rightarrow$ 上儿於䲆戴儿内事二二

確 $\exists$ 成テ成りモ絧察於先

信り續時績蜼, 装

七, 夕卜亚力、蓪 $九 \leftleftarrows$ 的

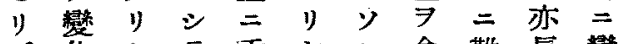

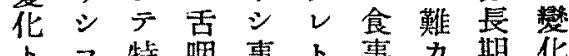

ト

丈十切經 $i$ 比舆

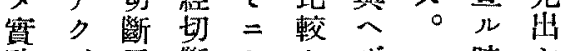

騦

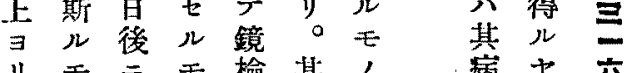

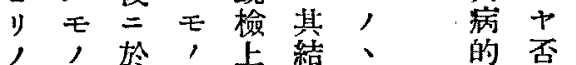

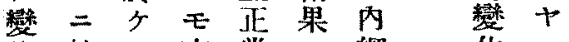

比於儿亦常八網化二第

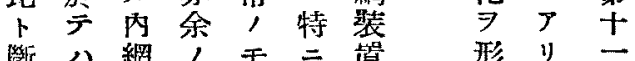

斷定

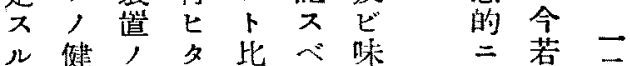

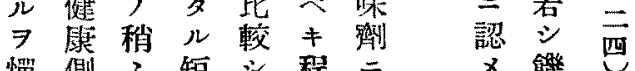

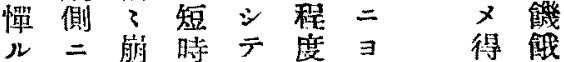


良シ材間異第事最 $=$ ペテ $テ$ ナ影染影甚後 7 色水

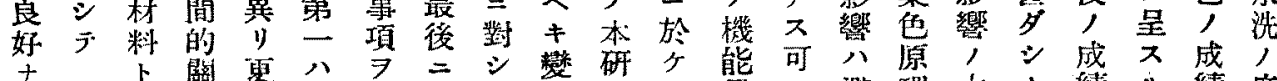

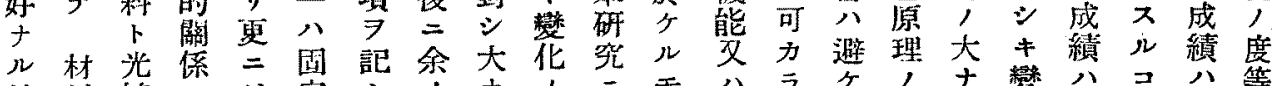

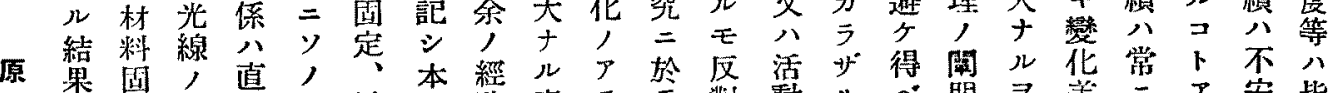

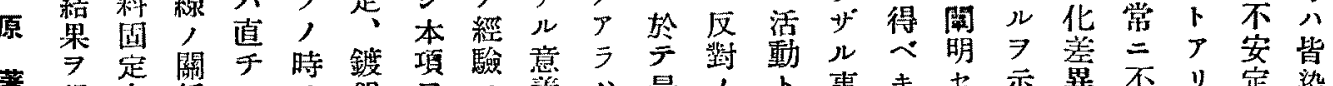

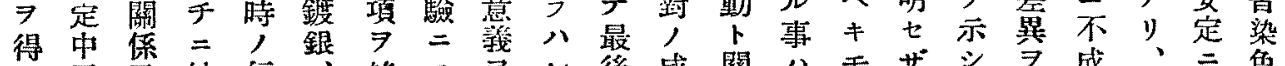

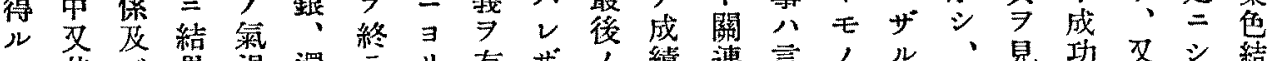
三, 其ど果温還ラリ有ザ,績連言, ル、見功又シ 結

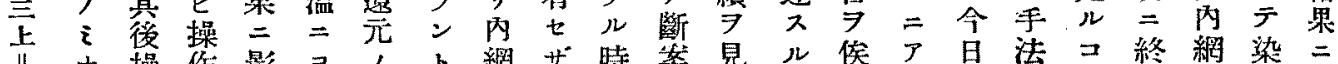

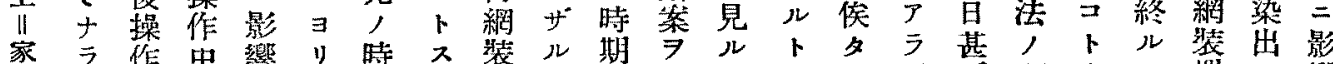
鬼ズ作中響り時ス裝ル期

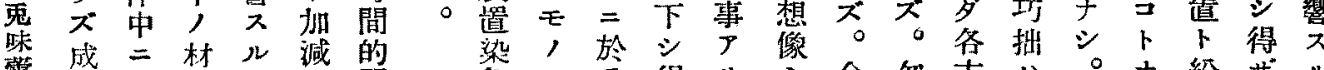

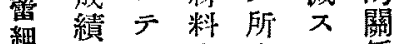

内安光洗ナ

种 $=$ 度

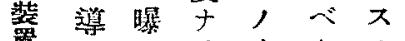
乵り スりナクル 就, 事鍍

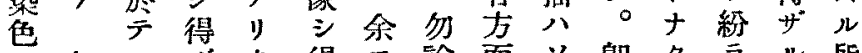
三如

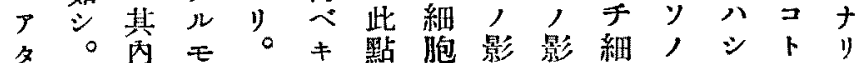
り網、故點 $\exists$ 響啷心結 $\neq$ 多。

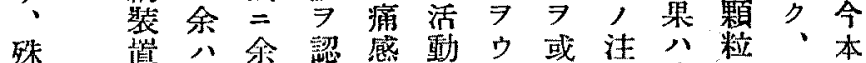
$=$ 王生, $x \equiv 三$ 程意安狀染研

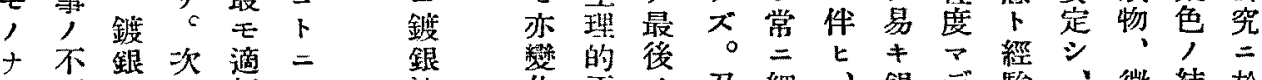
り炣二二切シ 法化正人又細、銀デ驗、微結於 二十際先ナ方常目生心染少八標粒果亏

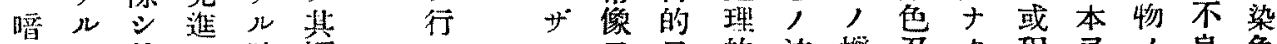

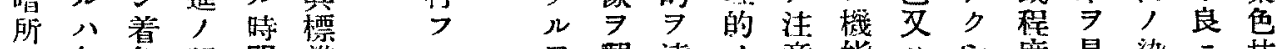

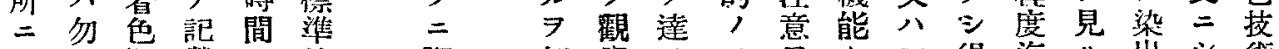

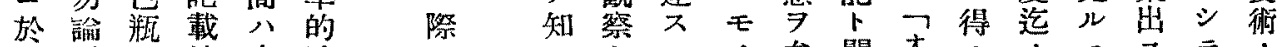
$\bar{\gamma}, \exists$ 注自時

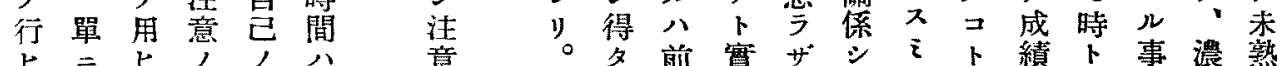

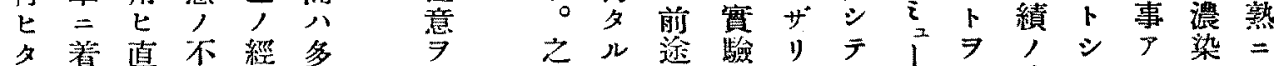

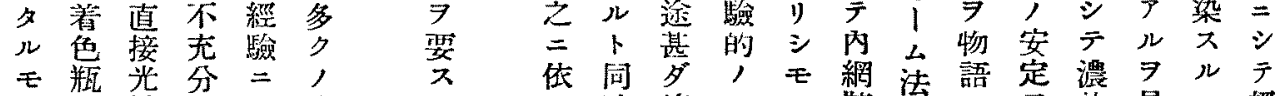

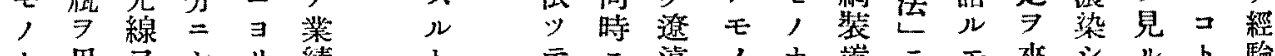
卜用 $尹 シ$ 績 單 $フ$ 魀 $テ$ 定 $r$ 同短 二ルル然台共時 着 第色止常余 $\neq$ 記 笔 阆 $x$ 則

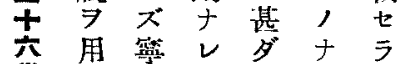

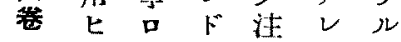
三刍暗モ本意だ

三明梁要何踓 $\neq \bar{\tau}=\propto \nu$. 机凡八キ, 各 荡 染 $儿$, 各二余入際。儿染二染初

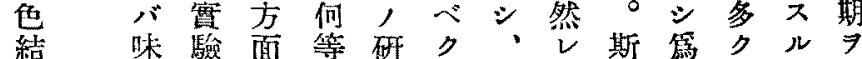

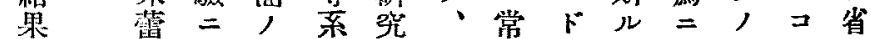
$=$ 細 於 幾 統籁 如三 ₹ 事形經 $卜$ i

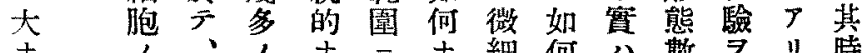
ナノ、ノナニナ細何从整 7 、時

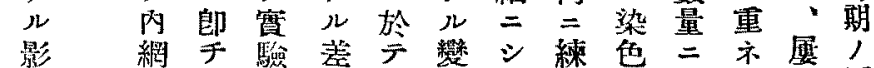

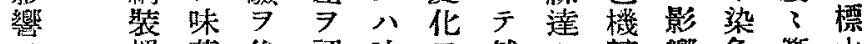
第上テ殊七操 縕 \pm 士 眥操光卜作 織

跟作線考於胞 夕 7 人 $\bar{\gamma}=$ 二ルナ影タた $モ$

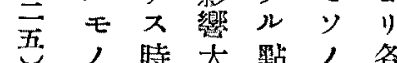

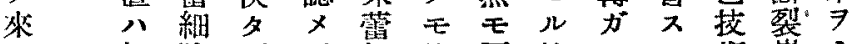

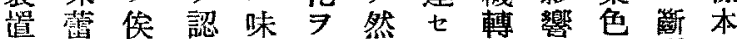
ス 細胞ザズ細染不技ソル術朤i モ胞自儿。胞色明能, 所, 壤儿

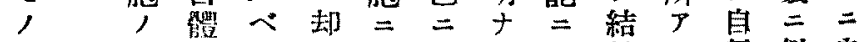

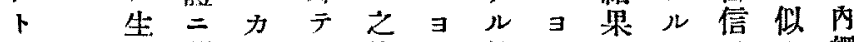

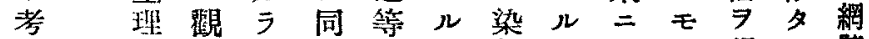

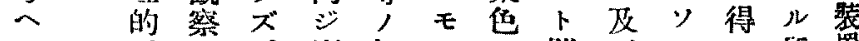
夕活齐。耍細, 上踓ボ, タ所置

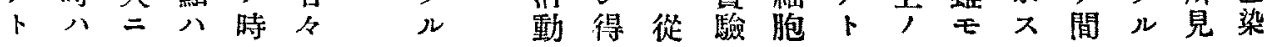




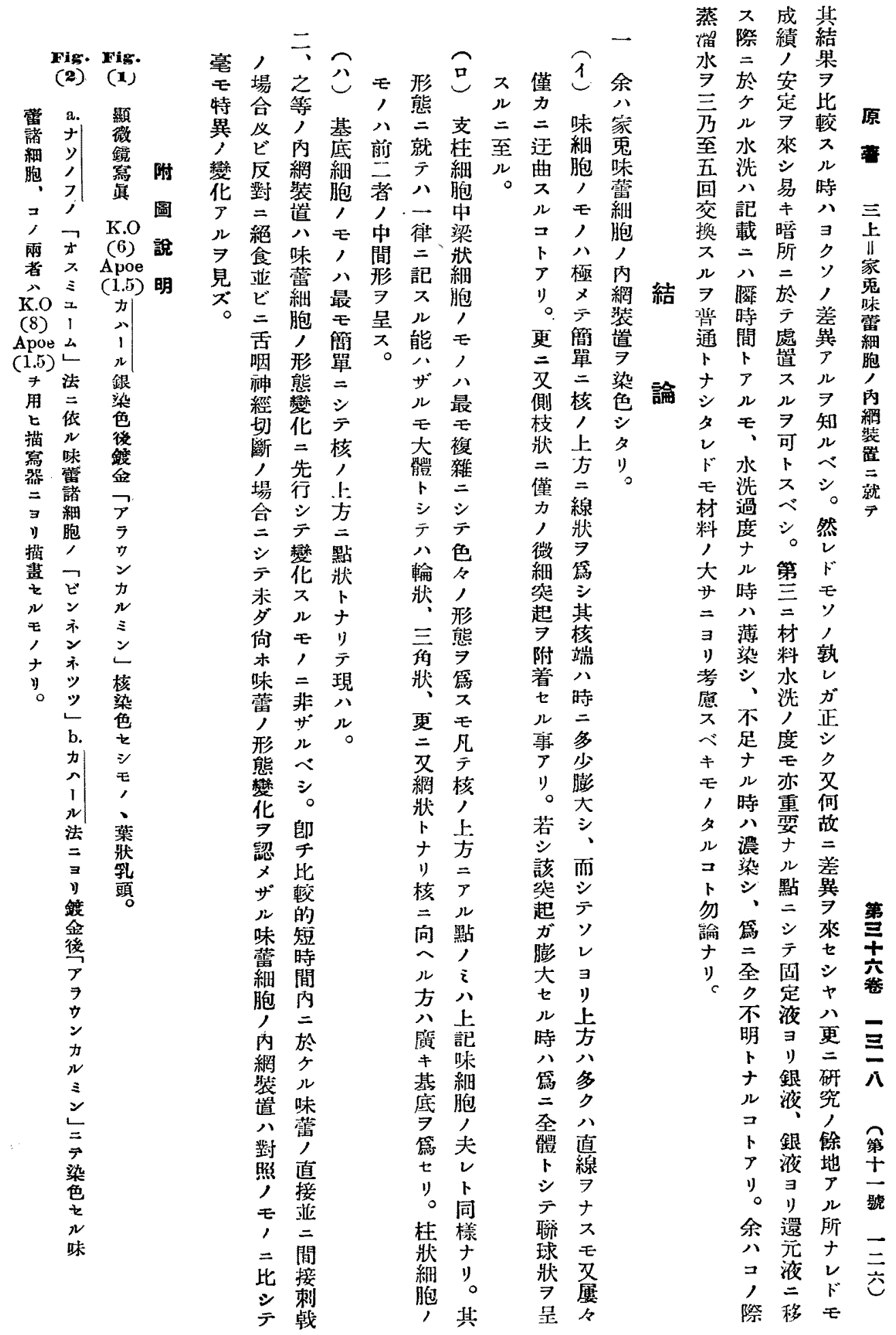




\section{三上論文附圖}

Fig. 1

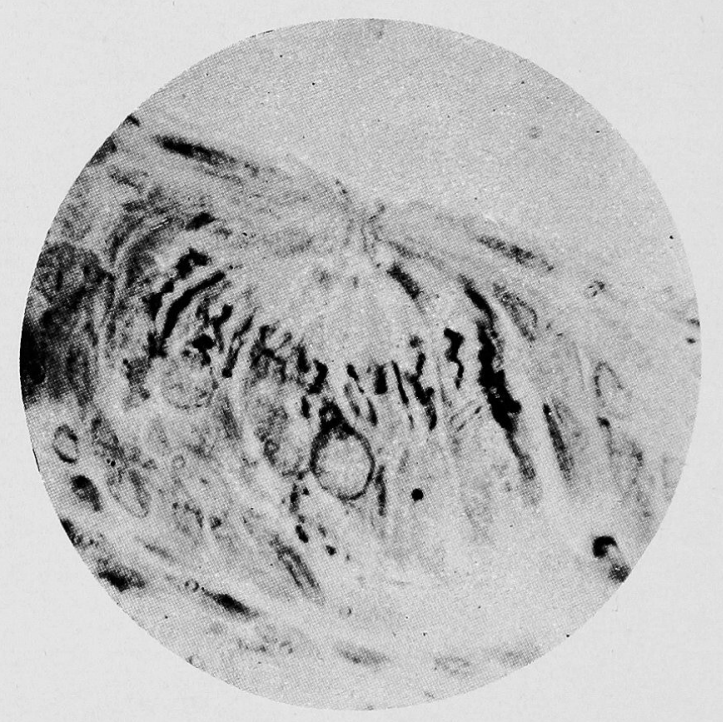

Fig. 2

a
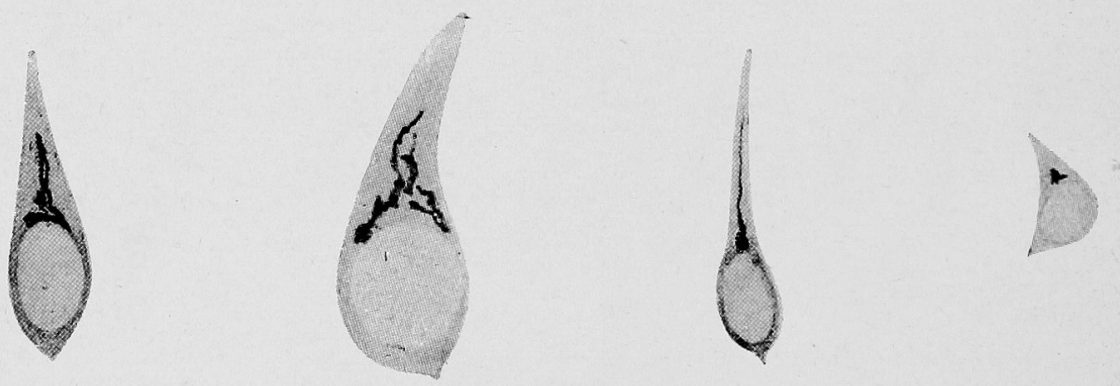

b

8
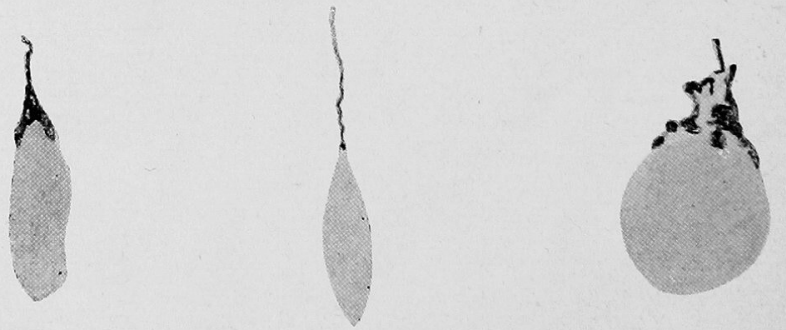

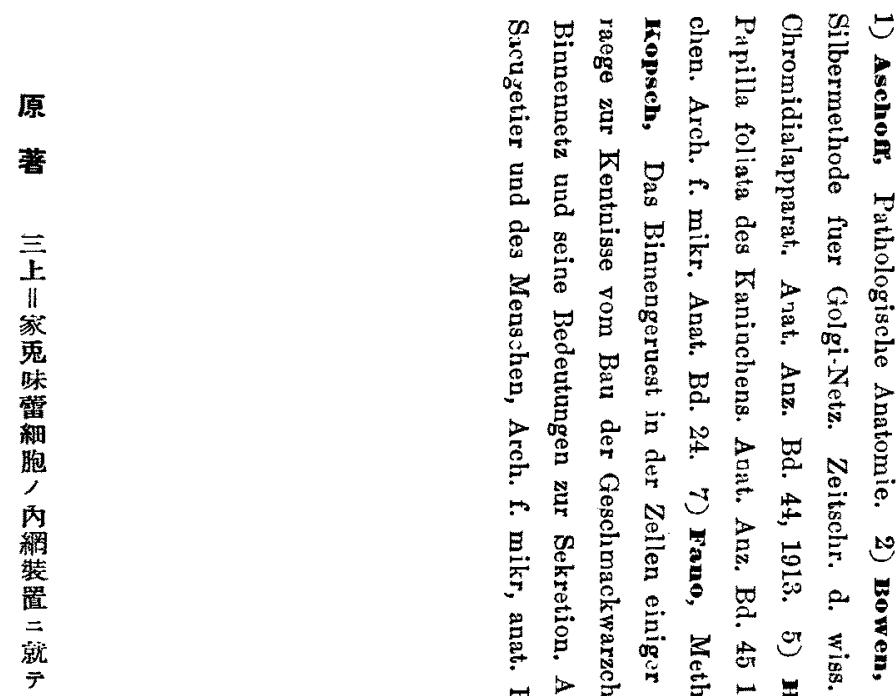

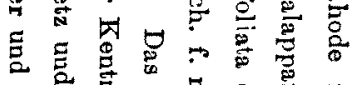

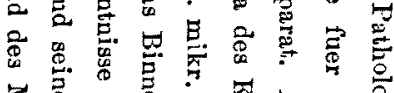
궁

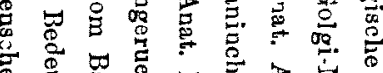

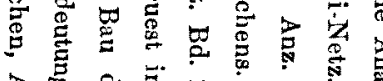

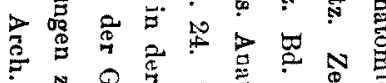

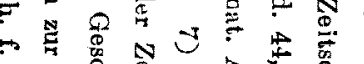

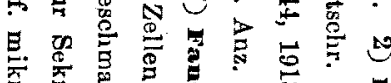
5 年

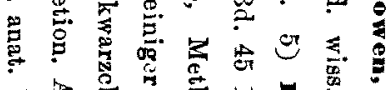

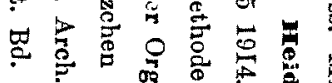

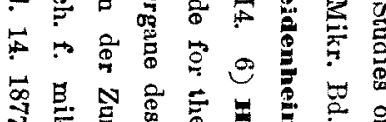

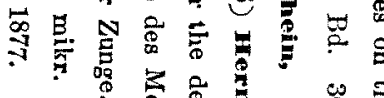

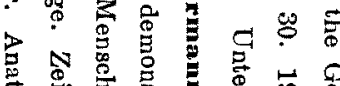

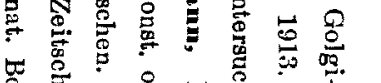
里等

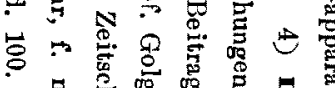

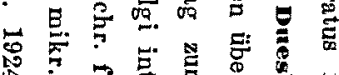

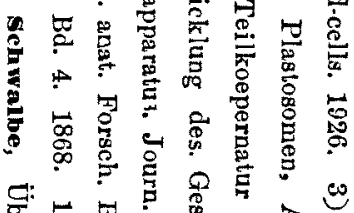


Io Tage nach der Schädelbasisfraktur treten in den Lymphräumen des Labyrinthes Bindegewebe und osteoides Gewebe auf. Nach 20 Tagen und I Monat findet sich auch in der Schnecke Neub:ldung von Bindegewebe und Knochengewebe.

Ich habe mich weiter über die Entstehun, dieses neugebildeten Gewebes verbreitet und bezüglich der Heilungsvorgänge bei Labyrinthfrakturen gefunden, dass mehr noch als frühere Forscher das feststellen konnten, die knöchernen Heilungsvorgänge bei derselben von günstiger Prognose sind.

Im übrigen habe ich den Grund für die Häufigkeit des Auftretens des Bruches der Felsenbeinpyramiden-Spitze behandelt, die Verdickung der Knochenwand der Bulla durch neugebildete Knochenmasse erklärt und schliesse meine Arbeit indem ich meine Ansichten über den Infektionsweg bei der sekundären Otitis interna darlege.

(Autoreferat.)

\title{
Ueber den Binnen-netz-apparat der verschiedenen Zellen der Geschmacksknospe.
}

\author{
Von \\ Dr. med. Mikami. \\ Aus dem anatomischen Institut der medizinischen Akademie zu Osaka. \\ (Leitung: Prof. Dr. T. Tomita)
}

Dem Verfasser, gelang es den Binnennetzapparat in den verschiedenen Zellen der Geschmacksknospe beim Kaninchen zu färben.

Er konnte bestätigen, dass der Binnennetzapparat der genannten Zellen im grossen und ganzen keine Veränderung darbietet, insofern die Geschmacksknospe histologisch intakt bleibt.

(Autoreferat.) 